\title{
Variation in Salivary Parameters with Respect to Caries Status among Study Subjects
}

\author{
Aastha Malik ${ }^{1}$, Sheeri Sabir ${ }^{2}$ and Smita Chandra ${ }^{3}$ \\ ${ }^{1}$ Kothiwal Dental College \& Research Center, Moradabad, India \\ ${ }^{2}$ Kothiwal Dental College \& Research Center, Moradabad, India \\ ${ }^{3}$ Kothiwal Dental College \& Research Center, Moradabad, India
}

Submission: September 16, 2017; Published: December 04, 2017

*Corresponding author: Dr. Aastha Malik, Department of Public Health Dentistry, Kothiwal Dental College \& Research Center, Moradabad, (U.P) 244001, Tel: 09690711100; Email: aastha.malik.02@gmail.com

\section{Abstract}

Statement of Problem: Saliva is a complex biological fluid containing several compounds which collaborate to prevent dental caries by mechanical washing, antimicrobial function, remineralisation and regulating oral $\mathrm{pH}$ by its buffering capacity. Protection against dental caries is dependent on both salivary quantity and composition of the secretions. With the former being the strongest, the quantity of saliva is the stronger risk indicator for dental caries.

Purpose: To access the variation in salivary parameters with respect to caries status among study subjects.

Material and Methods: A sample of 200 school children aged 12-15 years were recruited in the study from the private and government schools of Moradabad city. A specially prepared questionnaire was designed for collecting all the required and relevant information regarding socio-demographic status, caries status and salivary parameters. Assessment of all salivary parameters was conducted at the school premises, 1 hour after the study samples consumed afternoon lunch.

Result: Salivary flow, $\mathrm{pH}$, and buffering action in carious and non-carious subjects was found to be statistically significant, with non-carious group having higher salivary flow, $\mathrm{pH}$ and buffering action. Statistical significant difference was found between unstimulated and stimulated saliva with respect to salivary flow rate and salivary $\mathrm{pH}$, whereas buffering action was found to be non-significant.

Conclusion: Quantitative saliva assessment is useful as a screening method to identify patients with a low salivary flow rate, $\mathrm{pH}$ and buffering capacity. Such patients are at a higher risk for dental caries and other mucosal disorders, and if properly screened, preventive measures can be taken.

Keywords: Saliva; Caries status; Salivary parameters

\section{Introduction}

Saliva is a complex biological fluid containing several compounds which collaborate to prevent dental caries by mechanical washing, antimicrobial function, remineralisation and regulating oral $\mathrm{pH}$ by its buffering capacity [1]. It originates from major and minor salivary glands and non-glandular sources such as crevicular fluids, oral microorganisms and host cells [2]. Decreased salivary flow can lead to rampant dental caries, speech dysfunction and difficulty in swallowing as well as mucosal infections $[3,4,5]$. Protection against dental caries is dependent on both salivary quantity and composition of the secretions, with the former being the strongest [5,6], the quantity of saliva is the stronger risk indicator for dental caries [7]. Information on epidemiological figures of dental caries is a fundamental requirement which updates our knowledge on changing trends of the disease, its treatment needs and helps in understanding ways and means to prevent its onset, limit its progression, and consequences [8]. Alaluusua and Renkonen 1983; Caufield et al. 1993 stated that, children who experience colonization by mutans streptococci early in life are at greater risk of developing dental caries than those who are colonized later [9]. The final result, "caries to be or not to be", is a complex phenomenon involving internal defense factors, such as saliva, tooth surface morphology, general health, and nutritional and hormonal status, and a number of external factors-for example, diet, the microbial flora colonizing the teeth, oral hygiene, and fluoride availability [10]. It is generally accepted, that saliva secretion and salivary components secreted in saliva are important for dental health. So the study was done to access the variation in salivary parameters with respect to caries status among study subjects. 


\section{Materials and Method}

A cross sectional analytical study was conducted among school children aged 12 -15 years of Moradabad city to know the variation in salivary parameters with respect to caries status. Ethical clearance was obtained from institutional ethics and review board Kothiwal Dental College \& Research Centre Moradabad. Approval from school authorities and informed consent from the parents were obtained. A sample of 200 school children who fulfilled the inclusion and exclusion criteria were recruited in the study from the private and government schools of Moradabad city. The sample was divided equally into 2 Groups i.e. carious and non-carious groups. Children taking medication linked to alteration of saliva or having any systemic disease, wearing orthodontic appliances, having psychological disorders, motor disorders were excluded. A specially prepared questionnaire was designed for collecting all the required and relevant information. The questionnaire included questions regarding socio- demographic status i.e. name, age, father's name, mobile no, caries status, and salivary parameters. Responses of study subjects to the questionnaire will be assessed by the examiner. Salivary parameters such as, salivary flow, salivary $\mathrm{pH}$ and buffering action were assessed with the help of GC saliva check kit. Manufacturer instructions were strictly followed .Before the ingredient been chewed, baseline salivary parameters of unstimulated saliva were measured, Then the study samples were given paraffin wax to be chewed for 5 minutes and later on stimulated salivary parameters were assessed at the time interval of 5-10minutes.

\section{Method of Assessing Unstimulated Saliva}

The child will sit in an upright position with his head inclined forward so that the production of saliva is collected in the floor of mouth and then flows out over the lip. Saliva formed is let to drip into the graduated test tube or measuring cup for 5 minutes. The results of this collection are expressed as millilitre per minute.

\section{Method of Assessing Stimulated Saliva}

The child will chew the paraffin wax for five minutes, before the collection the first portion of saliva is swallowed. Start the timer and chewing is continued for 5 minutes .The saliva is spit out in a measuring cup for 5 minutes. The collected saliva is then measured; measurement should not include the foam which is formed during collection. The results are expressed as millilitre per minute. Assessment of all salivary parameters was conducted at the school premises, 1 hour after the study samples consumed afternoon lunch. The statistical analysis was done using SPSS (Statistical Package for Social Sciences) Version 16.0 Statistical Analysis Software. Statistical significant value was set at $\mathrm{p}$-value $<0.05$.

\section{Results}

On comparing salivary flow, $\mathrm{pH}$, and buffering action among carious and non-carious groups in both stimulated and unstimulated saliva, it was found to be statistically significant , with non-carious group having higher salivary flow, $\mathrm{pH}$ and buffering action (Table $1 \& 2$ ). On comparing the salivary flow rate and salivary $\mathrm{pH}$ of unstimulated and stimulated saliva, the results were found to be highly significant with the p-value (0.0001), whereas buffering action was found to be nonsignificant i.e. p-value (1.000). (Table 3).

Table 1: Salivary parameters in unstimulated saliva among carious and non-carious groups

\begin{tabular}{|c|c|c|c|c|c|c|}
\hline & $\begin{array}{c}\text { Caries } \\
\text { Status }\end{array}$ & $\mathbf{N}$ & Mean & $\begin{array}{c}\text { Std. } \\
\text { Deviation }\end{array}$ & T-Value & P-Value \\
\hline $\begin{array}{c}\text { Baseline } \\
\text { Flow }\end{array}$ & C & 98 & 2.6 & 0.63 & 10.1 & $<0.001$ \\
\hline NC & 102 & 3.4 & 0.49 & & \\
\hline $\begin{array}{c}\text { Baseline } \\
\text { pH }\end{array}$ & $\mathrm{C}$ & 98 & 6.23 & 0.2 & 18.13 & $<0.001$ \\
\hline $\begin{array}{c}\text { Baseline } \\
\text { Buffering } \\
\text { Action }\end{array}$ & $\mathrm{C}$ & 98 & 5.84 & 0.89 & 29.31 & $<0.001$ \\
\hline \multicolumn{1}{|c|}{} & $\mathrm{NC}$ & 102 & 6.76 & 0.21 & & \\
\hline
\end{tabular}

Table 2: Salivary Parameters in Stimulated Saliva among Carious and Non-Carious Groups.

\begin{tabular}{|c|c|c|c|c|c|c|}
\hline & $\begin{array}{c}\text { Caries } \\
\text { Status }\end{array}$ & $\mathbf{N}$ & Mean & $\begin{array}{c}\text { Std. } \\
\text { Deviation }\end{array}$ & T-Value & P-Value \\
\hline $\begin{array}{c}5-10 \mathrm{~min} \\
\text { Flow }\end{array}$ & $\mathrm{C}$ & 98 & 4.93 & 0.67 & 6.79 & $<0.001$ \\
\hline & $\mathrm{NC}$ & 102 & 5.57 & 0.67 & & \\
\hline $\begin{array}{c}5-10 \mathrm{~min} \\
\text { pH }\end{array}$ & $\mathrm{C}$ & 98 & 6.5 & 0.19 & 16.24 & $<0.001$ \\
\hline $\begin{array}{c}\text { 5-10min } \\
\text { Buffering } \\
\text { action }\end{array}$ & $\mathrm{C}$ & 98 & 6.34 & 0.89 & 29.31 & $<0.001$ \\
\hline & NC & 102 & 6.97 & 0.22 & & \\
\hline
\end{tabular}

Table 3: Comparison of unstimulated and stimulated salivary parameters with caries status.

\begin{tabular}{|c|c|c|c|c|c|}
\hline Salivary Parameters & Caries Status & Un stimulated Saliva & Stimulated Saliva & T-Value & P-Value \\
\hline \multirow[t]{2}{*}{ Flow } & $\mathrm{C}$ & 2.6 & 4.93 & 25.08 & $0.0001^{*}$ \\
\hline & NC & 3.4 & 5.57 & 26.402 & $0.0001^{*}$ \\
\hline \multirow[t]{2}{*}{$\mathrm{pH}$} & $\mathrm{C}$ & 6.23 & 6.5 & 9.689 & $0.0001^{*}$ \\
\hline & NC & 6.76 & 6.97 & 6.973 & $0.0001^{*}$ \\
\hline \multirow[t]{2}{*}{ Buffering Action } & $\mathrm{C}$ & 5.84 & 6.34 & 0 & 1 \\
\hline & NC & 10.83 & 11.23 & 0 & 1 \\
\hline
\end{tabular}




\section{Discussion}

Saliva is a most valuable oral fluid that often is taken for granted. It is critical to the preservation and maintenance of oral health, yet it receives little attention until quantity or quality is diminished. Etiology and pathogenesis of dental caries is multi factorial. Role of plaque properties in relation to caries formation has been recognized for a long time [11]. One of the property of dental plaque is its ability to concentrate inorganic constitutes, such as calcium and inorganic phosphates [12]. The fermentation of dietary carbohydrates by oral microorganisms, particularly Mutans Streptococci (MS) in the dental plaque plays a key role in the development of dental caries [13]. The contribution of saliva to the demineralization remineralisation process points to the importance of monitoring salivary flow [14]. The current study was done to know the variation in salivary parameters with respect to caries status among study subjects. On comparing salivary flow, $\mathrm{pH}$, and buffering action among carious and non-carious groups in both stimulated and unstimulated saliva, it was found to be statistically significant, with non-carious group having higher salivary flow, $\mathrm{pH}$ and buffering action. Saliva consists of various organic and inorganic compounds like bicarbonate, calcium, phosphate ions etc, to maintain its saturation. The consequence of this saturation establishes thermodynamic driving force, which is favourable for remineralisation and unfavourable for demineralization. Dental plaque is a structure of vital significance as a contributing factor, at least to the initiation of caries lesion [15]. Increased Calcium and Phosphorous, that would pass into a solution with a fall in pH i.e. critical pH would be lowest of all in non-carious group will maintain the aqueous phase in saturated condition [16]. If the fluid adjacent to the tooth is supersaturated with calcium and phosphorous ions at a given $\mathrm{pH}$ the enamel certainly cannot undergo demineralization at its surface [17] and this is one of the reason of higher salivary flow rate, $\mathrm{pH}$ and buffering action among non-carious group in both stimulated and unstimulated saliva. Shaw et al. [18] also showed that the level of calcium and phosphorous are significantly high in plaque of the children with no caries experience than those who are caries susceptible. Low salivary buffering capacity, low calcium and phosphate levels show a pronounced link to increased caries. Lower salivary flow rate found in carious group might be associated with a number of predisposing factors such as lack of raw material (water), lack of stimulus to salivary gland or could be a problem with salivary gland itself. As a result of low salivary flow rate, salivary $\mathrm{pH}$ and salivary buffering action will also get reduced [19]. Reduced salivary flow rate and the concomitant reduction of oral defense systems may cause severe caries and mucosal inflammations [10]. On comparing the salivary flow rate and salivary $\mathrm{pH}$ of unstimulated and stimulated saliva, the results were found to be highly significant with the p-value (0.0001). Saliva bathes the oral cavity 90 percent of the time, and its $\mathrm{pH}$ usually is higher in stimulated saliva [20]. The higher the flow rate, the faster the clearance [10] and the higher the $\mathrm{pH}$ and buffer capacity [21]. The protective effect of saliva are increased greatly by stimulation strategies. For salivary stimulation it should be considered as part of an overall preventive regime for an at-risk patient. These may include eating patterns which leads to saliva stimulation, as well as the use of stimulants e.g. Toffees, lozenges, lollipops, chewing gums etc. however toffees, lozenges etc. increases the salivary flow but has more deleterious effects due to sugar content and sticky nature [22]. Bots has hypothesized that the initial increase in flow rate is probably induced by the gustatory stimulus by chewing the products, however, during the continued chewing the loss of flavour and less quantity of the product can lead to a reduced stimulation of periodontal mechanoreceptors, which may contribute to the decrease in salivary flow rate, which ultimately will decrease the $\mathrm{pH}$ and buffering action of saliva [23].

\section{Conclusion}

Caries is a multi factorial disease and other risk factors including saliva exists are, socio-economic status and lack of access to dental care were shown to be risk factors for caries. The infectious nature of dental caries has already been known for decades. Ever since the recognition of Streptococcus mutans as the main microbial factor in the etiology of caries disease, a vast amount of work and effort has been devoted to the characterization of this bacterium. Saliva is one of the most important factors in prevention of dental caries. Therefore, physical and chemical changes in saliva composition and particularly changes in its buffering capability play an important role on development and progression of caries. Quantitative saliva assessment is useful as a screening method to identify patients with a low salivary flow rate, $\mathrm{pH}$ and buffering capacity. Such patients are at a higher risk for dental caries and other mucosal disorders, and if properly screened, preventive measures can be taken.

\section{References}

1. Malekipour MR, Messripour M, Shirani F (2008) Buffering capacity of saliva in patients with active dental caries. Asian J Biochem 3: 280-283.

2. Spielmann N, Wong DT (2011) Saliva diagnostics and therapeutic perspectives. Oral Dis 17(4): 345-354.

3. Mandel ID (1989) Impact of saliva on dental caries. Compend Suppl (13): S476-S481.

4. Stookey GK (1939) The effect of saliva on dental caries. J Am Dent Assoc 139(Suppl): 11S-17S.

5. Dodds MW, Johnson DA, Yeh CK (2005) Health benefits of saliva: a review. J Dent 33(3): 223-233.

6. Sreebny LM (2000) Saliva in health and disease: an appraisal and update. Int Dent J 50(3): 140-161.

7. Leone CW, Oppenheim FG (2001) Physical and chemical aspects of saliva as indicators of risk for dental caries in humans. J Dent Educ 65(10): 1054-1062.

8. Munjal V, Gupta A, Kaur P, Garewal R (2013) Dental caries prevalence and treatment needs in 12 and 15-year-old school children of Ludhiana city. Indian Journal of Oral Sciences 4(1): 27-30. 
9. Zhan L, Cheng J, Chang P (2012) Effects of Xylitol Wipes on Cariogenic Bacteria and Caries in Young Children. JDR Clinical Research Supplement 91(7 Suppl): 85S-90S.

10. Lenander LM, Loimaranta V (2000) Saliva and dental caries. Adv Dent Res 14: 40-47.

11. Rankine CA, Moreno EC, Vogel GL, Margolis HC (1985) Micro-analytical determination of $\mathrm{pH}$, calcium and phosphate in plaque fluid. J Dent Res 64(11): 1275-1280.

12. Dawes, Jenkins GN (1962) Some inorganic constituents of dental plaque and their relationship to early calculus formation and caries. Arch Oral Biol 7: 161-172.

13. Thaweboon S, Suddhasthira T, Thaweboon B, Soo-Ampon S, Dechkunakorn S (2007) Plaque pH response to snacks foods in children with different levels of mutans Streptococci . Southeast Asian J Trop Med Public Health 38(3): 598-603.

14. Humphrey SP, Williamson RT (2001) A review of saliva: Normal composition, flow, and function. J Prosthet Dent 85(2): 162-169.

15. Gordon N (1985) Understanding dental caries, etiology and mechanism , basic and clinical aspects 211.

This work is licensed under Creative

Commons Attribution 4.0 Licens

DOI: 10.19080/IJCSMB.2017.03.555620
16. Schroeder HE (1963) Inorganic contents and histology of early dental calculus in man. Helvodont Acta 7: 161-172.

17. Norman $\mathrm{OH}$, Arden OH Primary preventive dentistry ( $4^{\text {th }}$ edn).

18. Shaw L, Murray JJ, Burchell CK, Best JS (1983) Calcium and phosphorous content of plaque and saliva in relation to dental caries. Caries Res 17(6): 543-548.

19. Kaur A, Kwatra KS, Kamboj P (2012) Evaluation of non-microbial salivary caries activity parameters and salivary biochemical indicators in predicting dental caries. J Indian Soc Pedod Prev Dent 60: 212-217.

20. Dawes C (1987) Physiological factors affecting salivary flow-rate, oral sugar clearance, and the sensation of dry mouth in man. J Dent Res 66: 648-653.

21. Panu Rantonen (2003) Salivary Flow And Composition In Healthy and Diseased Adults. University of Helsinki, institute of dentistry 66-69.

22. Walsh LJ (2008) Clinical Aspects of Salivary Biology For The Dental Clinician. Journal of Minimum Intervention In Dentistry 2(1): 1-14.

23. Bots CP, Brand HS et al. (2004) Preferences and saliva stimulation of eight different chewing gums. Int Dent J 2004; 54(3): 143-148.

\section{Your next submission with Juniper Publishers} will reach you the below assets

- Quality Editorial service

- Swift Peer Review

- Reprints availability

- E-prints Service

- Manuscript Podcast for convenient understanding

- Global attainment for your research

- Manuscript accessibility in different formats

( Pdf, E-pub, Full Text, Audio)

- Unceasing customer service

Track the below URL for one-step submission https://juniperpublishers.com/online-submission.php 